Meta

Journal des tradlucteurs

Translators' Journal

\title{
English Idiomatic Phrases in the Nigerian Linguistic Environment: The Cultural Imperative
}

\section{J. O.J. Nwachukwu-Agbada}

Volume 38, numéro 3, septembre 1993

URI : https://id.erudit.org/iderudit/001858ar

DOI : https://doi.org/10.7202/001858ar

Aller au sommaire du numéro

Éditeur(s)

Les Presses de l'Université de Montréal

ISSN

0026-0452 (imprimé)

1492-1421 (numérique)

Découvrir la revue

Citer cette note

Nwachukwu-Agbada, J. O. (1993). English Idiomatic Phrases in the Nigerian Linguistic Environment: The Cultural Imperative. Meta, 38(3), 582-586.

https://doi.org/10.7202/001858ar

\section{Résumé de l'article}

L'analyse de l'anglais parlé au Nigeria montre que les expressions idiomatiques y subissent une double adaptation culturelle et linguistique. Cette transformation reflète une interférence au niveau de la conceptualisation qui valide en partie l'hypothèse de la relativité linguistique de Whorg. 


\section{ENGLISH IDIOMATIC PHRASES IN THE NIGERIAN LINGUISTIC ENVIRONMENT: THE CULTURAL IMPERATIVE}

\section{Résumé}

L'analyse de l'anglais parlé au Nigéria montre que les expressions idiomatiques y subissent une double adaptation culturelle et linguistique. Cette transformation reflète une interférence au niveau de la conceptualisation qui valide en partie lhypothèse de la relativité linguistique de Whorg.

Ayo Bamgbose (1971) once declared that "of all the heritage left behind in Nigeria by the British at the end of the colonial administration, probably none is more important than the English language. This is now the language of government, business and com- merce, education, the mass media, literature and much internal as well as external communication."1 This seems to be a reiteration of a special report on English language teaching in Nigeria published in 1966 in which a bogus claim was made for English to the effect that it had become "the national language of Nigeria" and then went on to assert that English was "the language of government, the language of instruction in the schools, the language of business and commerce, the language of internal communication among Nigerians of differing language backgrounds... and, of course, the language of international communication." 2 Nobody would doubt all that, but what is not clear is the extent to which these functions ascribed to the English language are strictly and religiously performed by the language alone. As L.A. Sofenwa (1975) has observed,

Even though the civil service which used to be the most prestigious and largest employer of labour, merchantile houses and other well established employers still insist that a candidate for employment should have a 'credit' in the school certificate English language examinations, it will be interesting to know how much English is actually used in the day-to-day discharge of official duties and in communication with colleagues, superiors and the public. ${ }^{3}$

Part of what is responsible for the situation in which a designated official language is undetermined by a resort to the mother tongue is traceable to the linguistic environment or what Sapir-Whorfian school of linguistic theory would refer to as linguistic relativity. According to Benjamin Whorf (1956),

... the world is presented in a kaleidoscopic flux of impressions which has to be organized by our minds - and this means largely by the linguistic systems in our minds. We cut nature up, organize it into concepts, and ascribe significances as we do, largely because we are parties to an agreement to organize it in this way - an agreement that holds throughout our speech community and is codified in the patterns of our language. The agreement is, of course, an implicit and unstated one, but its terms are absolutely obligatory. ${ }^{4}$

One of Whorf's vocal critics has been Joshua Fishman who has dismissed the hypothesis as untenable even while admitting the existence of a limited relativity or more appropriately, linguistic reflection. According to him, what Whorf considers as being hinged on linguistic relativity, that is the structuring of verbal interaction among linguistic settings, "are clearly linguistic reflections of sociocultural structure rather than being clearly and solely linguistic constraints that inescapably and interminably must bring about the particular behaviour to which they are supposedly related." 5

The crucial issues in these positions are the factors of environment and culture and what place they 
occupy in linguistic mediation. The Whorfian position is easily misunderstood because of the impression that the shape of the world is solely determined by our language in which case translating from one language to the other or even the concept of second language learning would have been impossible. Rather than be the case, on the contrary, there must exist experiences which we must share as human beings irrespective of the language we use, for to translate a text from one language into another in which the beauty and metaphysical properties of the original text are still largely realized means that certain experiences are universal in spite of differing environments and cultures. Be that as it may, the Nigerian linguistic environment is one in which culture serves as a mediating factor in shaping and remodelling the received English fixed phrases and proverbial expressions. This has given rise to what is now referred to as Nigerian English, and has further necessitated the question such as was asked by Ayo Banjo (1970): "Are we going to teach Nigerian children to use English exactly like their counterparts in Britain, or are we from the very beginning going to teach Nigerian English - a brand of English that is socially acceptable in Nigeria and at the same time internationally intelligible?" 6 The question is yet to be answered in official documents, but it is already taking care of itself. There is a streak of idiomatic phrases that one now hears and accepts without being embarrassed as to their correctness. But before we return to examine the Nigerian variant of the English idioms, it may be useful to situate the background to the recent posture in the Nigerian linguistic setting vis- $\dot{a}$-vis the attitude and concretization of approaches to the imported language, which though official, is being manipulated to subserve the cultural demands of the Nigerian society.

The place of the English language in Nigerian and African linguistic culture is one which had become a favorite chore of local scholars and writers for nearly three decades now. Some of the utterances in relation to the role of English language are out of sheer patriotic zeal meant to jettison a foreign language whose retention continues to be a sad reminder of the phenomenon of colonialism and imperialism. There are others who see the English language in Nigeria as a legacy worth preserving, a heritage with a binding force, without which the communication among the two hundred and fifty ethnic groupings or thereabout would have been impossible. Some others would not want the English language as it is spoken and written as correct to be violated. For instance, it is now clear that the cold reception Amos Tutuola's quaint novel, The Palmwine Drinkard (1952) got at home is traceable more to the weird English in which it was written than to the position held by P. O. Dada (1986) namely, that Tutuola was "only repeating to them (Nigerians) tales ... they [had] heard several times in the past." 7 One wonders how many Nigerians before the publication of the novel had been able to imagine the kind of expensive gothic plane through which Tutuola takes his readership, even as the tales are Yoruba and Nigerian. Rather than subscribe to Dada's view, one suspects that the place of the English language in Nigeria in the fifties ${ }^{8}$ is accountable for the seeming rejection of Tutuoal's devilish story. This was a time when emphasis on correctness of usage, particularly as "a good working knowledge of English ... remained a prerequisite for passing examinations and taking up government appointments. Thus a knowledge of English continued to be a desirable asset for Nigerians." 9 In 1963 , barely three years after Nigeria's attainment of political independance, Obi Wali was bold enough to ask for the repudiation of English or for that matter foreign languages as creative and cultural mediums in Africa because "the whole uncritical acceptance of English and French as the medium of educated African writing is misdirected and has no chance of advancing African literature and culture." $\mathrm{He}$ described African writers writing in foreign languages as "pursuing a dead end which can only lead to sterility, uncreativity and frustration." 10

One of the notable responses to Wali's diatribe came from Chinua Achebe (1965). He would not challenge the place of English in the Nigerian, and African speech community because of the imperatives of colonial experience across the continent. Rather than over-throw it, he would be prepared to appropriate it to serve his own ends. Says he, "I have been given this language and $I$ entend to use it... I feel that the English language will be able to carry the weight of my African experience. But it will have to be a new English, still in full communion with its ancestral home but altered to suit its new African surroundings." 11 The object of this paper is to examine the fate of English idiomatic phrases as they find themselves in the Nigerian linguistic environment. In other words, how has the Nigerian user of English setphrases adapted them to suit their Nigerian circumstances as horse of speech? Rather than wander into the controversy as to whether or not English should stay in Nigeria, 12 one is here interested in how the imperatives of environment and culture have worked in concert to re-fashion imported idiomatic expressions as to give rise to partially or totally new idioms that are able to bear the weight of Nigerian and African experience.

For purpose of space and moderation we can examine only a few of such phrases with a view to determining and establishing the impact of the cultural input that has gone into their new forms, even if in minimal mutations. The English fixed phrase, other things being equal which ordinarily is used to express a situation in which conditions would remain the same or alike except for the point in question, is meant to read all things being equal. In other words, there are many things to be regulated, and it is understood that the : point of consideration is free and adjustable once other factors are kept in check. All things establishes a universe; other things to the Nigerian does not seem to situate this prerequisite very well. The use of other gives the notion of an 
unstable, volatile condition whereas all indicates a deference to all mediating forces, both physical and spiritual. The traditional Nigerian approach to solving temporal and metaphysical problems is to control both the forces of the earth and those of the sky, the human and the extra-terrestrial mediators, for to neglect any of them is to risk a perpetuation of the problems. The Englishman would say more power to your elbow, but the Nigerian would prefer more grease to your elbow. To the latter, power is not located in the elbow although a freely swinging elbow, like a bicycle joint, needs to be greased, and if greased would work better. Power to the Nigerian resides in the muscles and not in the elbow. Rather than say beggars cannot or must not be choosers as the English would, the local user would say a beggar has no choice. The original English idiom sounds more unlikely. It does not seem to underline strongly enough the fact that the beggar is an utterly helpless fellow. In the original version of the idiom it is a situation that carries with it a possibility of a beggar picking an item of benefaction whereas the local variant is aimed at repudiating such a possibility. The emphasis in the Nigerian version is on the improbability of the choice at all. The Igbo say, onye nyere nwohu nkw arr $n^{\prime} k$ ? (who gave a roasted palmfruit to a slave?) Therefore, rather than say - as the received version tries to convey - who asked the slave/beggar to make a choice, the local variant seems to be questioning the rationality of making choices available to him by insisting that he has no choice. In other words, the chances are far more slimmer in the Nigerian usage than in its original form.

The Nigerian user of idioms - whether they are local or foreign - detests what ordinarily looks like an excessive use of words. What is observable in the use of local proverbs in Nigeria is that there is a continual effort to reduce the linguistic content of proverbial utterances as the years go by. A wordier version of a known proverbial saying usually attracts scorn and disapproval from those who are conversant with such an adage whereas a trimming of the same saw, while retaining its essential meaning, indicates mastery and great oratorical skill. Moreover, proverbial expressions in the Nigerian languages survive on their crispness, their frugality. What the Nigerian user of foreign idioms does - apart from converting their verbal picture to resemble what would make meaning in his social and cultural environment - is to seek to divest them, if possible, of excess baggage in verbal items. He, therefore, strips English idioms of particles which he considers as unnecessary with a view to sounding new and fresh, thus subjecting a foreign fixed phrase to the service of his own cultural speech performance demands. Where the Englishman would say, don't take the law into your own hands, the local speaker would remark, don't take laws into your hands. In he believes in gaining advantages by hook or by crook, the Nigerian version would read, he believes in gaining advantage by hook or crook. The English would observe that one is out of the frying- pan into the fire whereas the local user would say the person is out from frying pan to fire. Rather than say, my intention was not to hold him up to ridicule, the Nigerian variant is my intention was not to hold him to ridicule. Instead of I took him into my confidence, the Nigerian speaker would say, I took him into confidence. The Nigerian user relates to words on the basis of their practical conjurement in his mind's eye. Would this have anything to do with the so-called African low value for abstraction while being enthusiastic over those ideational strands of thought which would at once strike his imagination? It is so-called because the same African does anchor his rationality at more than one level of reality, a possibility which the African novelist has exploited with tremendous zeal and success. ${ }^{13}$ However, what is clear is that he organizes his value for terms on the grounds of their pragmatic signification; and this too is predicated on both his cultural horizon and his linguistic experience. For example, a word like below would appeal to him more than beneath because low in below already suggests a devalued estimation whereas neath conveys no such impression. This is possibly why the Nigerian user would say such an action is below his dignity rather than such action is beneath his dignity. If what he considers as a crucial word or words in an English idiom does not invite his imagination, he either forgets them or modifies them. The English speaker would remind you that sauce for the goose is sauce for the gander. The Nigerian user is not so conversant with sauce, and soup which should have substituted sauce in that idiom is never meant for animals in Nigerian culture; he has to look for another verbal item which would be there without very much altering the idiomatic meaning. He therefore replaces sauce with good so that the idiom now reads, what is good for the goose is also good for the gander. The use of also is important since the localized idiom seeks to convey a sence of balance and equity which in the first place made the use of good imperative. The sence of the pragmatic is also influential in the Nigerianization of the idiom, the taste of the pudding is in the eating. An Igbo proverb says ana ele ugu nwaany shiri na mbe (We rate the quality of the soup prepared by a woman in the gourd spoon.) The kitchenware - the gourd spoon - indicates tasting because it is with it that the soup preparation is assessed. The Nigerian speaker knows that in eating taste counts more than proof! The value of a meal would depend on how tasty it is; proof conjures up mathematical and dialectical figures and disputation. It may be a similar attitude that underlies his preference for he that dines with the devil... to he that sups with the devil..

He reorganizes an idiom such as don't drag someone else's name through the mire to read don't drag someone else's name in the mud. To the Nigerian, mud makes more meaning than mire which is only a component of a swampy and marshy ground. A fixed phrase such as Jane was delivered of a child yesterday is remodelled to read, Jane delivered a 
child yesterday. It was Jane that delivered the baby, meaning gave birth to the baby, and not a midwife because the baby is Jane's! The effort to emphasize Jane's role is located in the desire on the part of the local speaker to ascribe action to figures and objects on the basis of the quality of their significance in initiating results. For instance, if the native English speaker wants to impute that another person has an undue, corrupt advantage he speaks of the latter having a long arm. The Nigerian usage would accommodate and subscribe to his having long legs. It is the legs that are used to establish relationships with people. The English speaker knows that such relationships are possible without a face-to-face contact; the Nigerian speaker knows that at the current level of the country's technological development, a close, personto-person contact is crucial and this means taking trips to meet people in strategic positions. You will have to be near enough before you can thrust your long arm but before then you need to get that close by making use of your long legs to get to the action spot.

That expression or term which will suggest a ready imagery is preferable to the one that is hermeneutically circuitous, even if the same impression will be conveyed in the ultimate. This perhaps explains the popularity of the so-called obscene proverbs in traditional speech-making contexts. In his study of the sexual proverbs of the Yoruba people, J. O. Ojoade (1983) observes that, "a Yoruba using these proverbs is simply looking for the most appropriate vehicle to convey his message, his point, his ideas in a forcefull way... In a word, he likes to call a spade, a spade..."14 The intention of such users of rotten sayings is usually not to be vulgar or to make anybody laugh or amused just for the sake of it, but for stark and striking directness. In such discourse contexts, people who will laugh are the uninitiated; the mature and responsible listeners will be sizing the speaker to know how much of cultural practices in speech-making he knows and how relevant and picturesque his use of idioms are to the general direction of the linguistic context. This is one occasion when the rules of performance based on cultural and traditional tenets must be respected. Certainly for the Nigerian user of English idioms, fixed phrases and proverbial expressions has this performance relationship in the subconscious any time he speaks or writes. He must therefore think of recasting the idioms with a view to making them more memorable, with a view to deepening and permanentizing experiences and impressions. The words, dance and play exchange places in the English idiom, playing to the gallery. In local musical outings, usually on specific market days as in the Igbo cultural areas of Nigeria, the focus is on the dancer rather than on the player; admiration for the player is taken for granted, for he is a professional making a living. A dancer in traditional musical performances is the cynosure of everybody's eyes because he is almost always the demonstrating participant in the musical triangle of player, dancer and spectator whereas the player is often at the back- ground. In fact in the case of musical outings by agegrade, which were common, it meant that one who danced in a particular year might not have another opportunity the following year since it would be the turn of another age-grade, but the player or players might remain the same for years. Of course, the dancer is freer than the player and can gallivant to all corners of the gallery whereas the player, especially in traditional musical settings, is fairly fixed and concentrates on producing the culturally accepted notes and rythms. Again, rather than say, he delights in playing a person off against another, the Nigerian user would prefer, he delights in knocking people's heads together. The knocking of heads together evokes the precise picture of dangerousness and wickedness whereas the English variant seems to be leisurely over the heinousness of a gossip's gimmick. The phrase, knocking heads together reminds one of the Igbo term for it namely, ndugba, meaning to bring two or more things together with a rather colliding impact. Certainly these are native linguistic mediations which are ultimately transferred to infect the original English idioms, and which in fact makes the total repudiation of the Whorfian hypothesis more or less a challenge to reason and fact.

In conclusion, what are the implications of the cultural imperative in the structuring of Nigerian English idioms? The first observation to be made is that the Nigerian culture has affected practically all the facets of the English communicative structure, including pronunciation and the stress pattern. Secondly. although culture is not the only determinant of the variation of the original English idiomatic phrases, the choice to focus on it is to underscore the relatedness of language and culture. Thirdly, even if a two-way system of relationship does exist because the two, the study has opted to focus on one of the two-way connections as a way of calling attention to its dimension in translation, and also in the teaching and learning of English in Nigeria. Therefore, in speaking of a standard Nigerian English, 15 the two-way associations between language and culture must come in, because it is acceptability within a cultural and linguistic environment that dictates what will eventually be standard in that speech community. Interference features, at the level of conceptualization, for instance, partly uphold the Whorfian hypothesis of linguistic relativity. The fact is that the concept of being and reality varies from culture to culture and would influence the structure of the verbal system of a superimposed language such as English in Nigeria. The Nigerian user of the English language must not be apologetic over such a development, for the adventurer would always be exposed to risks, including the danger of death. But the English language in Nigeria is not dying yet.

J.O.J. NWACHUKWU-AGBADA School of Humanities, Imo State University, Okigwe, Nigeria 


\section{Notes}

1. Bamgbose, Ayo (1971): "The English Language in Nigeria", John Spencer (Ed.), The English Language in West Africa, London, Longman, pp. 35-37.

2. Robert Jacobs (Ed.) (1966): English Language Teaching in Nigeria, A Report of a Special Study, Lagos.

3. Sofenwa, L. A. (1975): "Teaching English as a Second Language in Nigeria: A Re-examination of Some Basic Assumption", Journal of Nigeria English Studies Association, 1\&2 (Dec), pp. 126127. For a similar observation, see Moboladji Adekunle, "Oral English in Nigeria: Relating Instructional Strategies to Sociolinguistic Realities", JNESA 8, 1 (May) 1976, p. 55.

4. Whorf, B. L. (1956): Language, Thought and Reality, J. B. Carrol (Ed.), New York, Willey, p. 212.

5. Fishman, Joshua (1972): Sociolinguistics, Rowley, Massachusetts, Newbury House Publishers, p. 93.

6. Banjo, Ayo (1970): "The English and the Nigerian Environment", JESNA 4, 1 (May), p. 50.

7. Dada, P. O. (1986): "The Tradition of the African Novel", Studies in the African Novel, S. O. Asein and A. O. Ashaolu (Ed.), Ibadan, Ibadan University Press, p. 31

8. See my review of Studies of the African Novel, S. O. Asein and A. O. Ashaolu (Ed.), Research in African Literatures, Texas, 18, 3 (Fall), 1987, p. 352.

9. Omolewa, Micheal (1975): "The English Language in Colonial Nigeria 1962-1960: A Study of the Major Factors Which Promoted the Language", JNESA, 7, 1\&2 (Dec), p. 108.

10. Wali, Obiajunwa (1963): "The Dead End of African Literature", Transition (Kampala), 10, p. 14.

11. Achebe, Chinua (1975): "English and the African Writer", Transition (Kampala), 18, pp. 27-30. The article is reprinted in Achebe's Morning Yet on Creation Day: Essays, Heinemann, London, 1975, pp. 55-62, under modified title.

12. Adama Odumuh's paper is optimistic that "the English language has taken firm roots in the Nigerian speech community... the language has come to stay." See his The Futur of English in Nigeria, 12th Annual Conference of Nigeria English Studies Association, University of Jos, 1981. However, Ime Ikiddeh's "English, Bilingualism and a Language Policy for Nigeria", Ibadan Journal of Hamanistic Studies, (October) 1983 , pp. 65-79 seems to be an effort at repudiating Odumuh's position. He believes that "the study of English is not taken half as seriously as it was twenty years ago," and this to him "is a loud signal for the development of as many of our indigenous languages as there are living groups of people who speak and transmit their culture through them."
13. Izevbaye, Dan (1986): "Reality in the African Novel: Its Theory and Practice", Présence Africaine, 139, 3rd Quarterly, pp. 115-135.

14. Ojoade, J. O. (1983): "African Sexual Proverbs: Some Yoruba Examples", Folklore 94, ii, p. 201.

15. See, for instance, Adekunle, Mobolaji A., "The Standard Nigerian English in Sociolinguistic Perspective", JNESA 6, 1 (May) 1974, pp. 24-27. 